\title{
Should Biden Apologize for Trump? National Remorse and the 2020 U.S. Presidential Election
}

\author{
Nick Smith ${ }^{1}$ \\ Accepted: 3 November 2020 \\ (C) Springer Science+Business Media, LLC, part of Springer Nature 2020
}

\begin{abstract}
This paper argues that if Biden wins the 2020 U.S. presidential election, his supporters should advocate for him to provide a value-declaring apology for what they consider the major offenses of the Trump administration. Such apologies differ considerably from categorical apologies, but they can provide significant meanings and serve substantive objectives during such a potentially volatile political transition
\end{abstract}

Keywords Transitional Justice $\cdot$ Donald Trump $\cdot$ Joseph Biden $\cdot 2020$ U.S. Presidential Election

\begin{abstract}
In recent years and even decades, too many people have forgotten that truth. They've forgotten that our ancestors trounced an empire, tamed a continent, and triumphed over the worst evils in history. In every generation, there have been cynics and critics that try to tear down America. But in recent years, the problem grew worse. A growing number used their platforms to denigrate America's incredible heritage, challenge America's sovereignty, and weaken America's pride.... America is the greatest fighting force for peace, justice and freedom in the history of the world.... We are not going to apologize for America. We are going to stand up for America. No more apologies.

President Donald Trump, 2018 U.S. Naval Academy Commencement
\end{abstract}

Let us stipulate two assumptions: 1) Joe Biden wins the 2020 U.S. presidential election; and 2) you support Biden over President Trump. If Biden wins the election, should you advocate for Biden to apologize for what you consider the offenses of the Trump administration? Trump supporters will of course object to the notion that anyone

Nick Smith

nick.smith@unh.edu

1 Department of Philosophy, University of New Hampshire, Durham, NH 03824, USA should apologize for the President, and this is instructive: we only expect apologies for things we find blameworthy, and what counts as an offense deserving of an apology is highly contested and an appropriate subject of political debate. An incoming president apologizing for an outgoing president might seem rather odd in a well-functioning democracy-opposing parties are supposed to disagree, so why would they bother with such rituals? Yet as we see most days in the news, apologies have increasingly become a battleground where moral boundaries are publicly policed, defended, and sometimes overtaken.

I have spent two books and many articles discussing apologies, and perhaps the adage applies as I consider the upcoming election: when you have a hammer, everything looks like a nail. ${ }^{1}$ My research spans the morally rich fine-grained nuances of the kinds of contrition that can save marriages, to the sorts of world-historical gestures of reconciliation that can prevent wars. Often when I receive an invitation to speak or write on political apologies, these discussions occur in the context of transitional justice where a war-ravaged or otherwise traumatized region hopes that an apology from the state for past wrongs will help facilitate a transition into a more just and stable period. Complexities abound, but similar questions tend to arise. Sometimes political apologies relate to events in the distant past such that no living people deserve obvious and uncontested blame for personally harming others. Apologies and reparations for the African slave trade, for example, present many complex issues distinct from, 
and often in addition to, the sorts of apologies needed in the context of transitional justice.

I have long found these issues important, fascinating, and in need of clear thinking from many different disciplines. But now we find ourselves in 2020, and the theoretical questions have become concretely urgent in my homeland. As a political philosopher with a background in law and the judiciary, I spend considerable effort trying to be evenhanded. When Barack Obama was president, I remember the visceral fear of some - not social media bots, but real people that break bread with me at my table - that he would take all the guns, institute sharia law, and become a communist dictator. They had been poisoned by so much vitriol that President Obama became dehumanized into a demonic caricature. Hoping to avoid the leftist version of this trap that divides and unhinges, I have tried not to believe the reverse image of this regarding President Trump.

But in early fall 2020, the coming presidential election evokes dread. Even for the most sober analysts, existential questions seem like reasonable concerns rather than classroom hypotheticals. The health of democracy in the United States has long been in question, but to what extent will it survive this election? Right and left both seriously doubt that the voting process will be legitimate. At such an explosive time when many children cannot even set foot in their school buildings, will COVID-19 sow further chaos and undermine the election process? Civil unrest related to police brutality and racial injustice further divides, and President Trump suggests that his heavily armed vigilante supporters who put down these "riots" should also "enlist" as "poll watchers." President Trump urges his Election Day Team Army to "cover every polling place in the country with people like you" to stop Democrats who will be "up to their old dirty tricks on Election Day." 2 And perhaps the most dangerous elephant in the room: even if the election process is clearly legitimate according to international standards, will there be a peaceful transition of power if Biden wins? Georgetown Law professor Rosa Brooks, founder of the bipartisan Transition Integrity Project, has "war gamed" possible election outcomes and concluded:

President Trump is likely to contest the result by both legal and extra-legal means, in an attempt to hold onto power. Recent events, including the President's own unwillingness to commit to abiding by the results of the election, the Attorney General's embrace of the President's groundless electoral fraud claims, and the unprecedented deployment of federal agents to put down leftwing protests, underscore the extreme lengths to which President Trump may be willing to go in order to stay in office. ${ }^{3}$

With Bush v. Gore as a precedent, do the judicial and legislative branches have the independence to enforce democratic processes? How will the police and military respond? We can forget that democracy is rare in human history, and when it does bloom it can seem like a rare and fragile flower in a field of robust authoritarianism. Usually we have other war-torn nations in mind when we speak of transitional justice, but that term is fluid. It isn't clear where the United States falls in 2020 on the spectrum of political turmoil, and future political theorists may treat us as a case study for any number of scenarios.

In this context I would like to raise the question of whether Biden - either as a presidential candidate or as eventual president-should do something like apologize for the United States, the Trump administration, or any particular actions or policies during the 2016-2020 period. It is easy to imagine Biden, with all of his mannerisms, uttering the words: "To my fellow Americans, you are owed an apology.... To the rest of the world, you also deserve better from the United States...." Usually I am rather skeptical of collective apologies. As much as a nation needs to "heal" from political trauma, too often apologies are snake oil. Whether from a corporate leader or a head of state, apologies from collectives often suffer from serious credibility problems. They can do more harm than good as they distort ancient traditions of interpersonal remorse to offer little more than ambiguous and cultic rebranding. With that healthy skepticism in mind, however, I do think Biden would be wise to offer a specific kind of apology for the Trump administration.

\section{Problems with Collective Apologies}

I developed a classification system and inventory for different varieties of apologies in I Was Wrong, with what I call the "categorical apology" being the exemplary interpersonal apology —or what we can consider a regulative ideal for apologies between individuals. That book considers a wide variety of apologetic meanings and warns against thinking of apologies in binary "all or nothing" terms. Instead, we should be clear about what we seek in apologies and evaluate them accordingly. In order to determine how close an act of contrition comes to a categorical apology, we can ask: Did the offender explain what she did with an appropriate degree of specificity? Does she accept blame rather than mere sympathy? Does she cast the offense as an accident or otherwise deny that it was her intention to harm? Does she make clear why her actions were wrong and identify the principles she violated? Does she promise not to do it again and redress the problem she caused? Does she fulfill those promises? There are many other relevant considerations - consider, for example, complex issues regarding emotions and apologetic meaning - but we can appreciate that collective apologies rarely provide the substantive moral transformation associated with categorical apologies from individuals. According to these guiding questions, an apology from Biden for Trump seems misplaced. Biden, it seems, cannot meaningfully apologize for Trump according to our basic intuitions regarding how apologies and blameworthiness work. 
We can unpack these intuitions by considering how issues related to standing and consensus present especially serious problems for collective apologies from heads of state. Usually we think of the person deserving of blame for wrongdoing as the person having "standing" to apologize, in part because the process of recognizing one's wrongdoing leads to changes in behavior, the need to remedy the harm, the appropriate emotional states, etc. But if Biden apologizes for Trump, we can appreciate just how different this would be than an apology from Trump-especially if Trump remains emphatically unapologetic and even ridicules Biden's apology. If Biden apologizes for the "United States," the problem of consensus arises quite forcefully. If I apologize to my wife, she has good reason to think that I am speaking univocally and that I agree with my own apology. If Biden apologizes for the "United States," a significant portion of the population will disagree with, oppose, and resent the apology. This is crucial for several reasons, including the possibility that the dissenters will continue committing the very offenses that Biden renounces and promises not to repeat. The stronger the consensus supporting the apology, the greater the likelihood the principles in the apology will be advanced rather than undermined by the members of the collective. If Trump supporters continue to wield political power with Biden as president, Biden's apology may not have much force in some jurisdictions. If an antiBiden candidate takes the Presidency in 2024, the principles in Biden's apology might be reversed outright. These dynamics are quite different from those of apologies from individual people who hopefully speak with one mind and who amplify the meaning of their apology by honoring it and not reoffending over time.

In addition, the victims of the Trump administration would receive quite different meanings from an apology from Biden than from an apology from those who harmed them. Only the offender can provide certain kinds of meaning, for instance by retracting an insult or symbolically bowing before the victim as a recognition of her humanity. We should not expect to see President Trump on a bent knee apologizing for disparaging wounded veterans, for example. Whatever Biden does or says to address this will be quite distinct from expression of remorse from Trump for these insults. Just like you cannot pay someone to exercise for you and confer those health benefits to your body, in some respects Biden cannot apologize for Trump.

Also note that Biden apologizing for Trump is too easy for both Trump and Biden. Biden can enjoy denouncing Trump's wrongs without accepting any personal blame. Trump will not need to do any of the labor of moral transformation nor will he feel the emotional pain of guilt, shame, and other negative emotions associated with remorse. Those with retributive instincts will be disappointed that Trump does not suffer.

\section{Value-Declaring Apology}

Despite these reservations, I am coming around to the view that Biden should provide some sort of apology. The United States is teetering on the erosion and possible collapse of our democratic institutions and principles. An apology from Biden, with all such an apology could entail, could help to frame the 2016-2020 period as anomalous, and signal to the world and to the country that the Trump administration should be viewed as an outlier. Like a friend or family member who needs to apologize for "out of character" behavior, Biden cannot leave the offenses unaddressed. Even if he wins the presidency and a relatively smooth transition of power ensues, it seems insufficient to sigh in relief and carry on without making explicit the moral and political principles that were breached, why we value those principles, how we will recommit to those shared values and remedy the harms done, and the various other sorts of meanings that political apologies can provide.

Rather than minimizing the significance of an apology from Biden because of shortcomings when measured against categorical apologies, we should conceptualize it as something more akin to a "value-declaring apology." 4 Valuedeclaring apologies emphasize policy commitments going forward, denounce breaches of those values in the past, and seek to remedy those offenses without needing to accept blame or precisely parse vectors of moral causation. Some might think of value-declaring apologies as undeserving of even being called an "apology," but their precision conveys practical benefits. Value-declaring apologies provide a different sort of tool, and they can be the right tool for the job.

As newly elected president, Biden would hold what I call "membership with rank" in the organization formerly occupied by the Trump administration. This confers standing to him to offer value-declaring apologies on behalf of the United States and the Office of the President of the United States. Like a new CEO apologizing in an attempt to recuperate share value after the failures of her predecessor, Biden would speak as the new leader correcting the course of the continuous organization by reckoning with past mistakes. Again, a leader with a clear claim of legitimate succession to an office can convey this meaning without personally absorbing blame for the wrongs and without perpetuating the metaphysical fiction that moral causation somehow persists in an unbroken chain between leaders.

I usually discuss value-declaring apologies in cases of transitional justice and failed states attempting to rebuild, but imagine a (rather unlikely) Democratic landslide in November that leaves progressives with overwhelming control of the U.S. government. And imagine they use this newfound power to prosecute, with gusto, every wrongdoer and lawbreaker in the Trump administration. The backlash to this might further factionalize the country and create even further 
instability as a sizable minority feels backed into a corner. We often need to finesse the issue of how to assign blame and responsibility for wrongdoing by the previous regime while preventing that very process from deepening wounds and political divides. However you understand justice, sometimes the process of "administering justice" can decrease political stability at a time when the threat of splintering into sectarian violence is especially dangerous. If moral accounting and punishment risks contributing to civil war, we might want to instead focus on describing and denouncing the wrongs of the past more generally, declaring the principles for the future, and providing remedies for those harmed. Value-declaring apologies can also accomplish systematic reform better than even exceptionally meaningful apologies between individuals. Although value-declaring apologies do not hit all the notes of categorical apologies, perfect apologies should not be the enemy of good apologies.

\section{Practical and Strategic Considerations}

Intertwined questions arise regarding political branding and the potential timing of such an apology. Would it be preferable for Biden to provide an apology during the election season or, if he wins the presidency, sometime after the election? For prudential and strategic reasons, I would advise a postelection apology for two reasons. First, having won the election would demonstrably increase the size of the consensus for which he speaks and add credibility to the assertion that he represents the majority of voters. Second, a pre-election apology from Biden would likely speak primarily to the converted. His supporters and those generally inclined from center to left would likely welcome such a gesture. But how would it be received by moderates, Republicans who disfavor Trump, and others who are not especially impressed by Biden and who may either not vote or cast a lukewarm party-line vote for Trump?

I cannot predict with any precision the impact of a Biden apology on his electability, but conservatives in the United States have a long history of viewing apologies as weak, emasculating, and unpatriotic. President George H.W. Bush repeated versions of this talking point whenever he could: "I will never apologize for the United States - I don't care what the facts are... I'm not an apologize-for-America kind of guy." One does not, on this view, want to be the "kind of guy" who grovels. This is an absolute belief held regardless of the facts. No matter how grotesque the offense, you do not want to be the kind of person who would ever adopt the posture of supplication. It is better, in this worldview, to be like cultural founding father John Wayne: "Never apologize. It's a sign of weakness." Apologizing, as President Trump might say, is for losers. Even Mitt Romney, who many see as a conservative ally against Trump, titled his vision for the country No Apology: The Case for American
Greatness. ${ }^{7}$ Some might think these are rather minor concerns considering everything else in play, but I would not underestimate the impact of these optics for Biden. The Democratic nominee has tried to walk the line between being an old-school tough guy with "law and order" gravitas and being an empathic statesman with a compelling bedside manner for victims of injustice. But for many, Biden is primarily Obama's vice president. And conservatives cast Obama as the "Apologizer in Chief" who went on various "Apology Tours" around the world "apologizing for America." "Should Biden open himself to such unpatriotic labels?

Whatever one thinks of President Trump, it is difficult to imagine him apologizing for anything. Instead of apologizing, he counterattacks. See, for example, his response to the Hollywood Access tapes: "Bill Clinton has actually abused women, and Hillary has bullied, attacked, shamed and intimidated his victims." "9 For President Trump, powerful people do not apologize. Powerful people command others to apologize and bow before them. Authoritarians have long demanded apologies, forced confessions, and other means to assert dominance over and dehumanize opponents. President Trump regularly tweets about who owes him an apology. It can seem odd that arguably the most powerful person in the world would take the time to demand an apology from a sportscaster, a newspaper, or Broadway performers. It seems beneath the office to continually air his grievances regarding who owes him an apology - why would a lion care about the views of sheep? - but the spectacle of demanding obedience while humiliating enemies and amplifying outrage serves his purposes.

The contrasts have been painted sharply. Obama was "Apologizer in Chief." Trump is "Never Apologize for America John Wayne." I do not know how damaging it would be for Biden to fall into these same categories, but if he adopts an apologetic tone he risks alienating centrists who have implicitly or explicitly endorsed the nationalist ideology against apologizing. We should not underestimate the power of such mythologies that idealize the United States and its history into a kind of religious faith, and we should brace for the vitriol directed at those who question the legitimacy of those narratives by dredging up things like slavery. There are always dark psychological undercurrents in elections, and we should be mindful of these dynamics around apologies and power, dominance, gender, and race.

These considerations suggest that if Biden plans to offer something like an apology for the Trump administration, he should wait until after the election. The timing of political apologies is a nuanced art, and in this case the sooner Biden offers such a gesture the better in order to declare his intentions and begin to remedy harms. In an ordinary election year, he might consider building these sentiments and plans into an acceptance speech, and perhaps he would revisit the principles and objectives of the apology at subsequent occasions. But given the rather unique concerns regarding peaceful transition of power and the likelihood that the election results will be contested, waiting until 
inauguration seems like a more prudent occasion to at least begin to articulate how an apology for the Trump administration will shape Biden's term.

If Biden does apologize for Trump, what exactly should he say and do? This would require a much more thorough and lengthy analysis, including how Biden will frame his own policies as corrections to Trump. There are many offenses that Biden might wish to identify as especially wrong or damaging, but leftist and centrist supporters will disagree about which issues should be prioritized and whether Biden should address broad principles or specific incidents. The broader he frames the values identified - such as restoring civility, empathy, racial equality, and democratic institutions - the more likely he will appeal to a broader constituency. Usually I look for precision in how an apology corroborates a factual record and attributes blame to culpable individuals, but such findings will likely require lengthy investigations to understand what happened, how it was allowed to happen, who did what exactly, and how to prevent it from happening again. Biden can use an apology early in his administration to announce the opening of these investigations. I would also advise against a general "airing of grievances" that attempts to identify and correct every problem with the Trump administration and with U.S. history. There are many compelling arguments for a robust apology and reparations for U.S. involvement in the slave trade, for example, and these underlie the racial tension and white nationalism that have erupted. But an apology for slavery deserves its own occasion. ${ }^{10}$

I would, however, pay special attention to how Biden addresses what many consider one of the greatest failures of the Trump administration: the dehumanization of minorities and those who oppose him. A central feature of meaningful apologies, I argue, is their ability to treat those who have been victimized as moral interlocutors. This means that a good apology can transform those who have been injured, demeaned, and treated as beneath the offender into someone recognized as having equal moral value. Biden is often described as empathic, and this plays to his strengths when contrasted with President Trump. Biden can help to restore the dignity of large groups of immigrants and minorities from the disparagement of these groups as "thugs" and other slurs, and he can make explicit that such name-calling is not acceptable. This seems like rather basic etiquette one learns in preschool, but its basicness speaks to how fundamental assumptions have deteriorated and require reinstatement. To return to issues related to standing, Biden elevating the humanity of immigrants can accomplish important meanings. But this is not the same as President Trump himself denouncing his own dehumanizing habits and recognizing those whom he disparaged as fellow humans of equal worth, just as it is different when your mom tells you that you are not a loser after the bully repeatedly tells you that you are.

Whatever Biden says and does in an apology, we should resist announcing the quality of the apology in the immediate aftermath. We can judge some aspects of an apology in the moment, but an apology is like a promise, and we need time to evaluate how Biden honors those promises. Does he provide leadership to remedy what he denounces, or does he fulfill the leftist prophecy that Biden is ultimately too similar to Trump on various issues? Apologies are a process requiring time for policies to develop and patterns of behavior to emerge. ${ }^{11}$ They are treatments, not cures.

In particular, we can observe how resources track promises made. In addition to a fulfilled promise to prevent similar offenses, victims often care most about financial redress. If Biden denounces failed leadership from the Department of Education and the Department of Health and Human Services during the COVID-19 pandemic, for instance, does he ultimately direct sufficient resources toward the education and public health systems? Value-declaring apologies can write checks as well as categorical apologies, and surely the Trump administration caused financial damages along many vectors. Should a Biden administration foot the bill for these financial wrongs caused by their predecessors? Even though Biden does not deserve blame for these harms, his official position makes him responsible for remedying the harms in the same sense that a janitor is responsible for cleaning someone else's mess. The post-COVID economy promises to further strain the resources and the political will required to provide redress.

An argument exists that we might consider some of this a kind of "odious debt" that might even be clawed back from the Trump administration and family. With origins at least as old as Aristotle's Politics, Alexander Nahun Sack described the odious debt doctrine:

when a despotic regime contracts a debt, not for the needs or in the interest of the state, but rather to strengthen itself, to support popular insurrection, etc., this debt is odious for the people of the entire state. The debt does not bind the nation; it is the debt of the regime, a personal debt contracted by the ruler, and consequently it falls with the demise of the regime. ${ }^{12}$

Usually such an argument would seem incompatible with democratic transferals of power between parties, but President Trump has presented a rather unique set of facts to analyze in this regard. It is tempting to expand the concept to "odious moral debt" in the context of value-declaring apologies, but that is a paper for another time. We can watch for answers to simpler questions and the more complex issues play out: Who pays? Who gets paid? How much?

Finally, part of the appeal of an apology from Biden for the Trump administration stems from the shift in tone from "no apologies" cynicism to empathic humanism. As with any apology, intentions matter. The public generally and rightfully will view a political apology like they perceive corporate apologies built to raise stock values and please focus groups. If 
Biden's apology looks like a transparent means to score points with various constituencies, it can backfire. His audience might perceive that not only is he "apologizing for America," but clumsily pandering and betraying national pride for cheap wins. Credibility, likability, and stature can suffer. Biden must be mindful of these risks and not fumble the opportunity.

\section{Conclusion}

I am usually one of the less optimistic and more cynical analysts of political apologies, but in fall 2020 I feel the appeal of such a ceremony to help restore the soul of my country. Of course nations have no souls, and the United States has never been pure-except to nationalist zealots. I hope to have outlined here how an apology from President Biden for the Trump administration could be meaningful, authentic, practical, and unifying even it is quite different from a categorical apology and even if Trump remains remorseless.

\section{Notes}

1. This essay expands upon, synthesizes, and applies arguments from I Was Wrong: The Meanings of Apologies (New York: Cambridge University Press, 2008). For a more thorough defense of the arguments suggested here, please see Part II of I Was Wrong on Collective Apologies. See also related arguments in "Apologies and Transitional Justice: Myths, Ideologies, and Complexities," Oxford Handbook of Transitional Justice, eds. Jens Meierhenrich, Alexander Laban Hinton, and Lawrence Douglas (New York: Oxford University Press, 2021); “Apologies as Remedies, Apologies as Weapons: Advice for Prime Minister Trudeau," University of Toronto Center for Ethics Journal, November 2017; “Apologies, Reparations, and Shattering the Founding Myths of the United States," The Critique, October 2016; "Political Apologies and Categorical Apologies," On the Uses and Abuses of Political Apologies, ed. Mihaela Mihai and Mathias Thaler (New York: Palgrave Macmillan, 2013): 29-43 (reprinted in Transitional Justice, ed. Christine Bell (New York: Ashgate, 2015); "An Overview of Challenges Facing Collective Apologies," Public Apologies Between Ritual and Regret, eds. Daniel Cuypers, Daniel Janssen, Jacques Haers, and Barbara Segaert (Amsterdam: Rodopi, 2013). This article also revisits material from Justice through Apologies: Remorse, Reform, and Punishment (New York: Cambridge University Press, 2014).
2. See https://www.armyfortrump.com/forms/electionday-team (accessed September 9, 2020); Katherine Doyle, "Trump Campaign team launches political organizing app in play to broaden digital reach," Washington Examiner, April 23, 2020 (accessed September 9, 2020).

3. See Jess Bidgood, "A bipartisan group gamed out a contested Trump-Biden election. Now they're offering recommendations," Boston Globe, August 3, 2020 (accessed September 9, 2020).

4. See I Was Wrong, 148.

5. Michael Kinsley, "Rally Round the Flag, Boys," Time Magazine, September 12, 1988.

6. She Wore a Yellow Ribbon, directed by John Ford, 1949.

7. Mitt Romney, No Apologies: The Case for American Greatness (New York: St. Martin's Press, 2010).

8. See, for example, the Heritage Foundation's essay by Nile Gardener and Morgan Lorraine Roach, "Barack Obama's Top 10 Apologies: How the President Has Humiliated a Superpower," June 2, 2009, available via http://www.heritage.org/europe/report/barack-obamastop-10-apologies-how-the-president-has-humiliatedsuperpower (accessed September 9, 2020). See also Edward Isaac Dovere, "Obama's Apology Complex," Politico, May 23, 2016, available via https://www. politico.com/story/2016/05/obama-asia-trip-hiroshimaapology-223446 (accessed September 9, 2020).

9. Jenna Johnson, "Trump Apologizes for 'foolish' Comments about Women, then Attacks Clintons," The Washington Post, October 8, 2016. Available via https:// www.washingtonpost.com/news/post-politics/wp/2016/ 10/08/trump-apologizes-for-foolish-comments-aboutwomen-then-attacks-the-clintons/?utm_term=. 68c68c85a9e8 (accessed September 9, 2020).

10. See "Apologies, Reparations, and Shattering the Founding Myths of the United States," The Critique, October 2016.

11. See Matt James and Jordan Stanger-Ross, "Impermanent Apologies: On the Dynamics of Timing and Public Knowledge in Political Apology," University of Toronto Center for Ethics Journal, November 2017.

12. Cited in Martha Minow, When Should Law Forgive (New York: W.W. Norton, 2019): 91. See pages 90102 for a discussion of the odious debt doctrine.

Publisher's Note Springer Nature remains neutral with regard to jurisdictional claims in published maps and institutional affiliations.

Nick Smith is a professor and chairperson of the University of New Hampshire Department of Philosophy. 